\title{
The National Landslide Database of Great Britain: acquisition, communication and the role of social media.
}

\author{
Catherine Pennington ${ }^{1}$, Katy Freeborough ${ }^{2}$, Claire Dashwood ${ }^{3}$, Tom Dijkstra ${ }^{4}$ and Kenneth Lawrie ${ }^{5}$ \\ British Geological Survey, Keyworth. Nottinghamshire. NG12 5GG. UK. Tel: +44 (0)115 9363100 \\ ${ }^{1}$ cpoulton@bgs.ac.uk ${ }^{2}$ karo@bgs.ac.uk ${ }^{3}$ cfoster@bgs.ac.uk ${ }^{4}$ tomdij@bgs.ac.uk ${ }^{5}$ mailto:kigl@bgs.ac.uk
}

\begin{abstract}
The British Geological Survey (BGS) is the national geological agency for Great Britain that provides geoscientific information to government, other institutions and the public. The National Landslide Database has been developed by the BGS and is the focus for national geohazard research for landslides in Great Britain. The history and structure of the geospatial database and associated Geographical Information System (GIS) are explained, along with the future developments of the database and its applications. The database is the most extensive source of information on landslides in Great Britain with over 17,000 records of landslide events to date, each documented as fully as possible for inland, coastal and artificial slopes. Data are gathered through a range of procedures, including: incorporation of other databases; automated trawling of current and historical scientific literature and media reports; new field- and desk-based mapping technologies with digital data capture, and using citizen science through social media and other online resources. This information is invaluable for directing the investigation, prevention and mitigation of areas of unstable ground in accordance with Government planning policy guidelines. The national landslide susceptibility map (GeoSure) and a national landslide domains map currently under development, as well as regional mapping campaigns, rely heavily on the information contained within the landslide database. Assessing susceptibility to landsliding requires knowledge of the distribution of failures, an understanding of causative factors, their spatial distribution and likely impacts, whilst understanding the frequency and types of landsliding present is integral to modelling how rainfall will influence the stability of a region. Communication of landslide data through the Natural Hazard Partnership (NHP) and Hazard Impact Model contribute to national hazard mitigation and disaster risk reduction with respect to weather and climate. Daily reports of landslide potential are published by BGS through the NHP partnership and data collected for the National Landslide Database are used widely for the creation of these assessments. The National Landslide Database is freely available via an online GIS and is used by a variety of stakeholders for research purposes.
\end{abstract}

Keywords: landslide, database, national, Twitter, thresholds, domains

\section{Introduction}

Great Britain does not experience extreme climatic or tectonic events, nor are there high mountainous regions associated with large scale, destructive landslides as seen elsewhere in the world. In terms of landsliding, Great Britain is a low risk environment (Gibson et al., 2013) with small scale failures and low fatality rates. Past events which represent significant impacts of landslides in Great Britain have been dominated by incidents that were large scale (e.g. Holbeck Hall, North Yorkshire; Lee, 1999), disruptive to transport routes and local economies (e.g. Rest and Be Thankful Pass, Argyll; Winter et al., 2010; Rothbury, Northumberland; British Geological Survey, 2012a) or involved isolated fatalities (Burton Bradstock, Dorset; British Geological Survey, 2012b; Whitehaven, Cumbria; Jenkins and Hobbs, 2007; Nefyn Bay, Gwynedd; Gibson et al., 2002). Detailed reviews of UK landslides can be found in Jones and Lee (1994) and Cooper (2007). The winters of 2012-13 and 
2013-14 and the summer of 2012 saw extensive periods of prolonged precipitation and a corresponding marked increase in the number of landslide events reported at both the coast and inland. These events had significant impacts on infrastructure and people (Pennington and Harrison, 2013; Fig. 1).

As a partner of the Natural Hazard Partnership (NHP), the British Geological Survey (BGS) has become a focus for issuing national daily hazard assessments for landslides related to weather. The collation of landslide data into a coherent national database is key to its continuing delivery of national advice and understanding of landslides in Great Britain. This paper provides an overview of the National Landslide Database in terms of traditional data acquisition methods that have been supplemented recently with the use of social media to both collect and communicate landslide information. Additionally, current scientific research and applications are summarised.

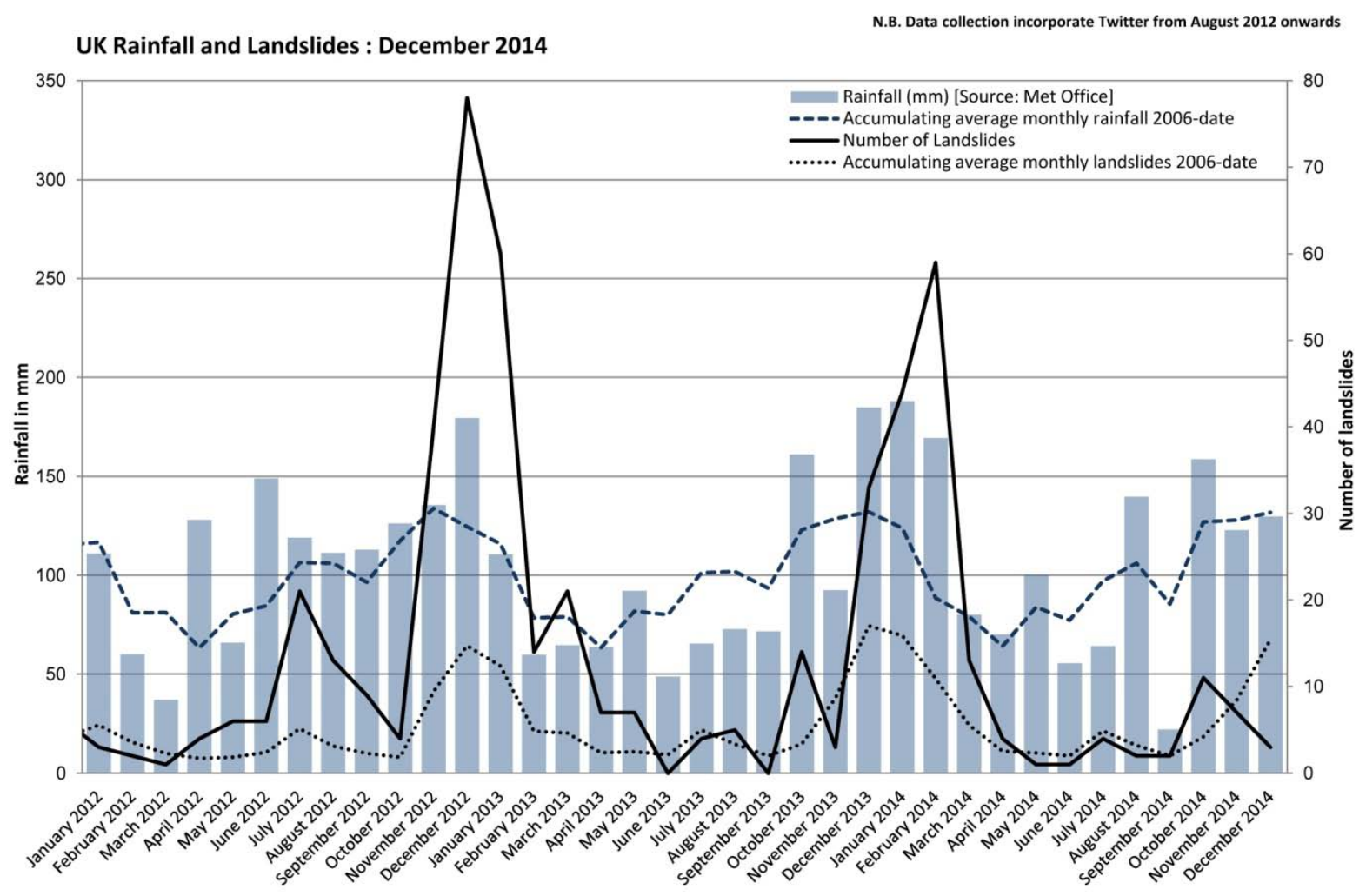

Figure 1 UK precipitation [Source: Met Office] and reported landslides (including slope failures on manmade slopes): January 2012 to December 2014. Social media were incorporated into the data acquisition methods from August 2012 onwards.

\section{The National Landslide Database of Great Britain}

The first version of the national landslide database of Great Britain was devised by the UK Government's Department of the Environment (DoE). The production of the DoE database was a much-needed first step in identifying the extent and significance of landslides in Great Britain. The relatively subdued topography and degraded nature of many ancient failures in Great Britain had meant that landsliding was not widely considered to be extensive or problematic. However, costly disruptions to projects in the 1960 s by reactivation of previously unrecognised landslides, for example, on the Sevenoaks By-pass (Skempton and Weeks, 1976) and the Walton's Wood motorway embankment (Early and Skempton, 1972) brought about a realisation that the extent of ground instability was not well understood or managed by developers or planners (Foster et al., 2012). This 
database documented approximately 8,500 records of landslides. Since 1995, the DoE database has been incorporated into and combined with other information from a range of data sources discussed in this paper and is now superseded by the BGS National Landslide Database (NLD). The details of the history, work flow, deficiencies and how the current version of the database addresses these are detailed in Foster et al. (2012).

The BGS NLD in its current form is, to date, the most comprehensive source of information on landslides (both inland and at the coastal) and slope failures (although this is a term widely used, for the purposes of the NLD, it is specifically reserved for landslides on manmade slopes) in Great Britain. Data are displayed in a GIS and there are currently over 17,000 records of landslide events on both natural and manmade slopes with each landslide documented as fully as possible (Fig. 2). Each landslide record can hold information on over 35 attributes including location, date, dimensions, landslide type and style, trigger(s), impact(s), vegetation, age, development and a full bibliographic reference to the source information (Fig. 3). For detailed description of these attributes and their definitions, see Foster et al. (2012).

The database consists of a series of related tables with constraining domains held and maintained in a corporately managed relational Oracle database schema as well as in an ArcMap10 Geodatabase, with a Microsoft Access front-end. Microsoft Access is a very flexible and user-friendly front-end tool for data entry and manipulation. The back-end database held in Oracle provides: (i) security; the data are backed-up both on- and off-line and are securely held and monitored; (ii) maintenance and management; Oracle allows the use of powerful tools for the maintenance and control of the data, including the granting of levels of access down to field level; (iii) accessibility; the data are readily accessible throughout the BGS and can be readily made available on a wide variety of both on- and offline platforms; (iv) outputs; use of Oracle Spatial(C)

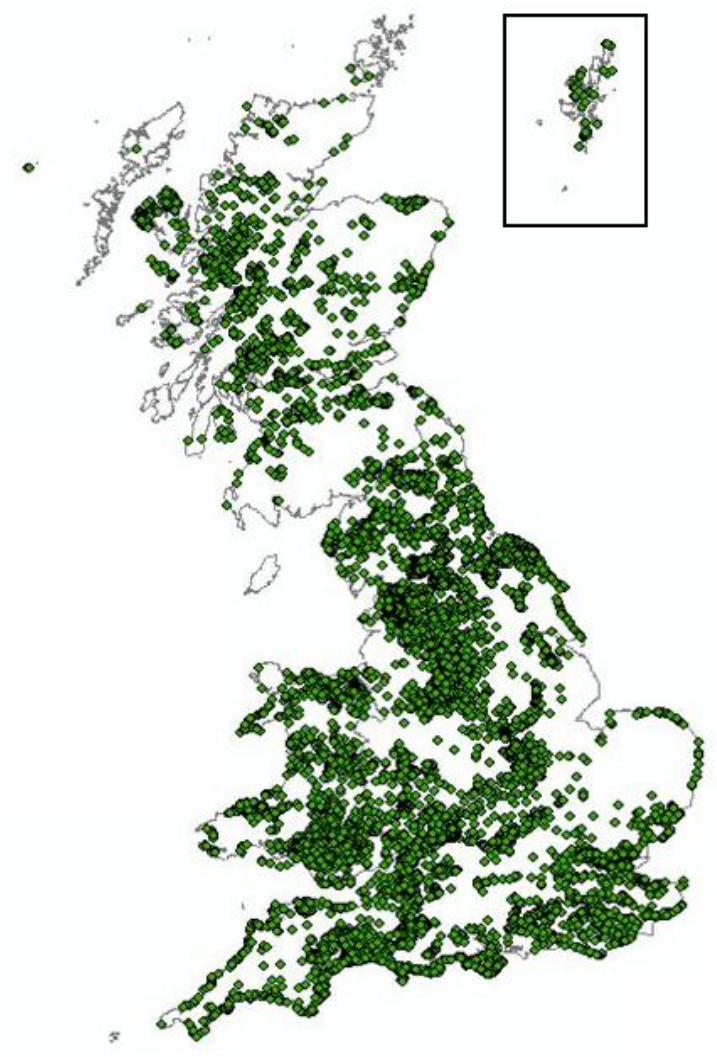

Figure 2 Spatial extent of the National Landslide Database. BGS (C) NERC 2015. All rights reserved. Contains Ordnance Survey data (coastline) (C) Crown copyright and database right 2015.

means that the spatial element of the data can be output in any coordinate system required without recourse to complex algorithms or export routines and subsequent manipulation; ( $v$ ) maintenance of history and transactions; the full history of data input, and any changes, is held and can be rolled back to any point; and (vi) interoperability; the power and capacity of an organisation-wide database, such as Oracle, means that a wide variety of datasets can be readily related to the landslide data, enhancing the potential for new science. 


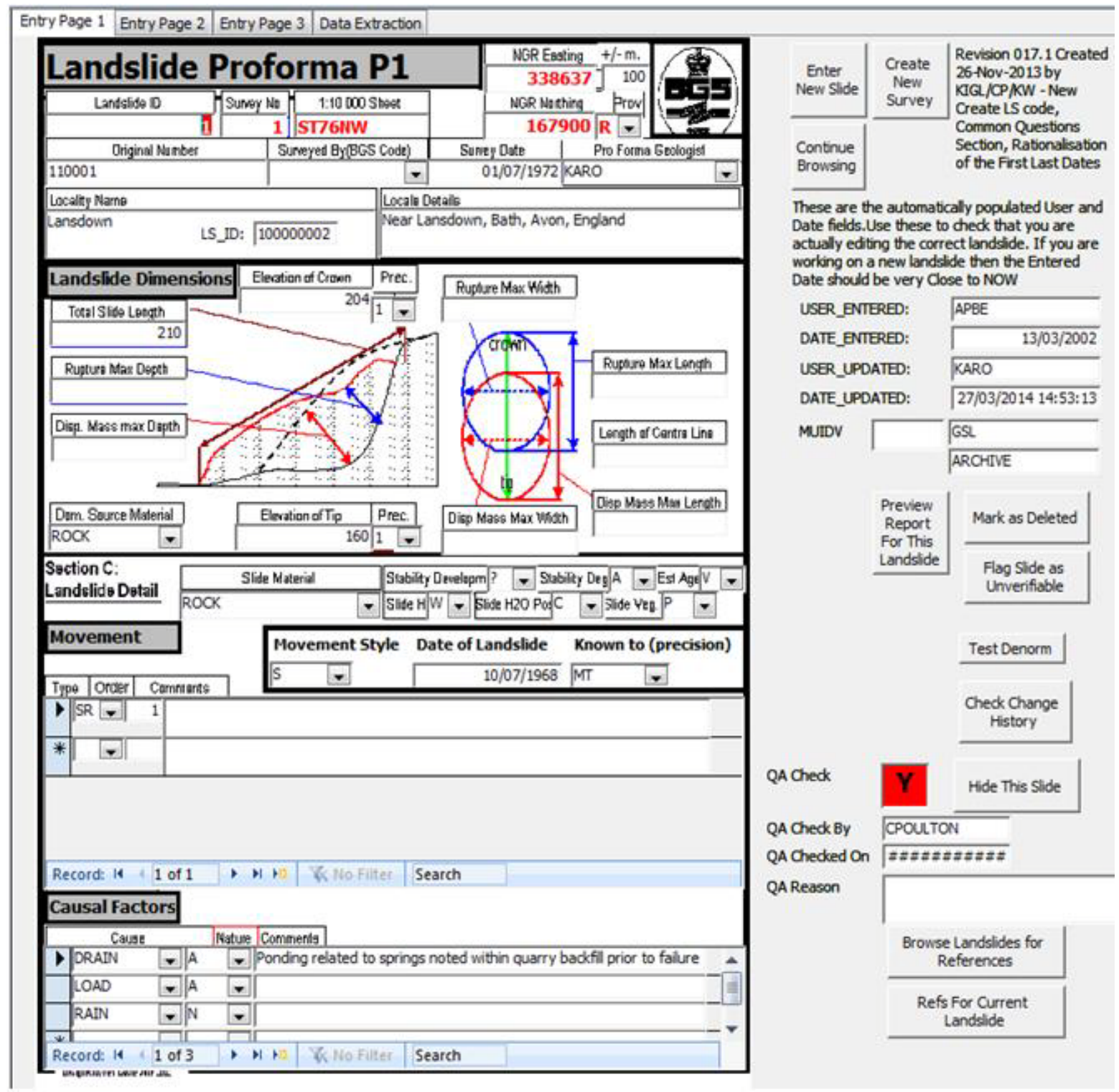

Figure 3 Screen dump of Page 1 of the National Landslide Database pro-forma for an example landslide in Bath, England (taken from Foster et al. 2012).

Each record represents a survey of a landslide event not a landslide per se, therefore enabling multiple reactivations of long-term continuously moving landslides to be captured in the database, which has been particularly useful in understanding the reactivation of a number of large scale landslides relating to antecedent rainfall conditions in areas such as the Isle of Wight in 2012-13 (e.g. Totland, St Lawrence and Headon Hill). Multiple movement events and surveys of the same landslide complex are captured as distinct episodes by giving each landslide record a compound unique identifier consisting of a Landslide ID and a Survey Number. Associated surveys are easily searched for in the database and displayed as separate points in the GIS.

The data are subject to a continuous Quality Assurance (QA) process and there are several integrated precision and accuracy fields that address this. For example, as the spatial extent of every landslide is not documented, each landslide record is located as point data on the highest point of the backscarp (or digital landslide polygon if backscarp information is unavailable). There are approximately 9,000 landslide polygons in the current BGS digital geological maps documented in the NLD; 7,800 records are from other mostly unmapped sources. The point is located to a 
12-figure grid reference and information as to how accurately this point was located is also included, allowing the user to indicate $\pm X \mathrm{~m}$ according to how this information was obtained. Date and dimensional information also have similar qualifiers and, as previously mentioned, all changes are recorded in the integrated history table. Details of dictionary definitions and database structure are described in Foster et al. (2012).

\section{Data Acquisition}

The NLD is continuously updated and expanded through both passive (searching for keywords in the news- and social-media) and active (fieldwork, papers, journals, reports, citizen science) means. These methods produce two groups of landslides incorporated in the database in terms of their acquisition: ancient and contemporary events.

Ancient landslides in the UK (i.e. those which occurred under different climatic conditions from those of today) are largely well constrained by centuries of geological mapping at a range of scales as well as BGS landslide surveys and databases (Foster et al., 2012). However, due to advances in mapping techniques and changing drivers for geological mapping, previously undiscovered ancient landslides are still being located through ongoing regional geological surveys (e.g. Pennington et al., 2009; Evans et al., 2013) and the published scientific literature and reports.

Contemporary reports incorporate landslides and reactivations on natural and, more recently, slope failures (see Section 2 for definition). While these slope failures are, by far, the most frequent landslide type in the contemporary data, they are often relatively small landslides occurring on engineered slopes that can be remediated within a few days; the associated impacts are often significant as they are capable of disrupting transport services and damaging property, infrastructure and businesses. This is in contrast to the less frequently reported, larger landslides on natural slopes that take many more resources and time to remediate. As well as assessing the potential for landslides to occur, it is important that impacts are recorded in the NLD to enable the likely consequences of future landsliding to be evaluated for the NHP daily hazard assessments.

The online press have been monitored for information about landslides through various Internet search engines since 2006 and recent work by Taylor et al. (This Issue) has further enhanced this process. In August 2012, incoming information from social media was incorporated into the search for contemporary landslide information.

Twitter, a popular micro-blogging tool where real-time observations are published to the web, has proved to be the most prolific source of information as it has for other geohazards such as earthquakes and tsunamis (e.g. Earle et al., 2011; Doan et al., 2012; Stollberg and de Groeve, 2012). This instantaneous reporting ('tweeting') mainly responds to events that have an immediate impact on society such as travel disruption and it has resulted in smaller landslides being captured in the NLD. Previously, these small events would not be as visible in the regional and national media and would thus have a much lower likelihood of being recorded in the NLD, particularly if they were remediated quickly.

Twitter is monitored for the occurrence of keywords (e.g. landslip, landslide, mudslide, rock fall etc). This is currently a manual process which enables irrelevant data to be ignored and individuals or authorities to be contacted for further information. The frequency of landslides in the UK and related tweets is currently such that this process is achievable by one person on a daily basis. The use of non-specialists to collect data, through citizen science is easily dismissed as 'soft data' and 
therefore not scientifically stringent; it could be presumed that such data have not been collected by a trained scientist so are inaccurate. In order to address this, the reported information, whether reported via social media or the local or national press, is used as a first alert to the existence of a landslide. This is then followed by contacting the relevant landowner or local council to get more detailed information and may result in a field survey. However, even if this information is not forthcoming this still provides a record of a landslide event in a spatial context. The data available are then used to populate the NLD.

Coupled with improved media search engines and the incorporation of slope failures, the use of social media as a data gathering tool has facilitated the increase from 10-15 (Gibson et al., 2013) to 150-200 new landslide events per year. As a result, care must be taken in the interpretation of Figure 1 as the number of landslides detected by media search engines and social media before August 2012 is fewer. This reflects a previously reduced capability in data gathering as opposed to fewer landslides occurring and is an inevitable obstacle to collecting data over long periods of time with respect to technological advancements.

The widespread use of smartphones has dramatically increased the incidence, detail and speed of data reported. In 2012, the number of smartphones worldwide topped one billion, and it is expected to double by 2015 (Shanley, 2013). The public are now well practised at, for example, taking a photograph of natural phenomena and uploading it to a social network such as Twitter, often within minutes of the event. The use of social media to inform the NLD enables factors such as the impacts, remediation and triggers to be captured the time of the event, many of which could be otherwise unknown. In addition to text description, photographs and video footage (both on the ground and from Unmanned Aerial Vehicles for example) provide invaluable data that would otherwise be impossible to collect on a national scale for any organisation attempting to populate a national database. In addition to social media, the public are also invited to actively report landslides through an online Report-A-Landslide form (British Geological Survey, 2007). Citizen science such as this is used to collect data on a range of geological hazards including landslides (Nyquist, 2012) and earthquakes (e.g. Bossu, 2013; Savran et al., 2013).

Without exception, all the contemporary landslides have been described in the news and social media because they have had an impact on society such as road diversions, rail delays, homes being demolished or the closure of coastal footpaths. While these are valid reports, the following scenarios must be considered to fully appraise the occurrence of landslides so as not to incorporate a false impression of events:

- the data represent an accurate picture of the true number of landslides occurring;

- the data are artificially high due to a heightened awareness of landslides through added media attention during wet periods;

- the data under-report the true number of landslides occurring, overlooking those where social impacts were insufficient to warrant reporting. This may be especially true for those larger and older landslides which may have started to reactivate but have no immediate impact for the public.

\section{Applications}


The NLD provides a constantly updating baseline dataset of landslide information for Great Britain. This feeds into several important areas of BGS landslide research:

\subsection{National Landslide Potential Map (GeoSure)}

GeoSure (Figure 4) provides a 1:50000 scale assessment for potential landslide hazard in Great Britain for inland landslides on natural slopes. A slope model forms the basis of the product, derived directly from a $25 \mathrm{~m}$ resolution NEXTMap ${ }^{\mathrm{TM}}$ digital terrain model (DTM) of Great Britain. This can be increased to a $5 \mathrm{~m}$ DTM for more regional studies. An additive algorithm is used to generate a score from different factors influencing slope stability including material strength, permeability, discontinuities combined with slope angle (Dashwood et al., 2014). The NLD does not directly feed into the algorithm but is used to groundtruth, support and interpret the data because an essential component of any susceptibility map is knowledge of the distribution of current failures and an understanding of causative factors and their spatial distribution.

\subsection{Natural Hazards Partnership}

The Natural Hazards Partnership (NHP), a collaboration between leading UK government agencies, provides a national assessment of natural hazards in the UK. Established in 2011, the NHP focuses on hazards that may disrupt the normal activities of communities or damage environmental services. These include: landslides, floods, drought, extreme temperatures, space weather, volcanic ash, earthquakes, wildfire, snow, ice, fog and air quality

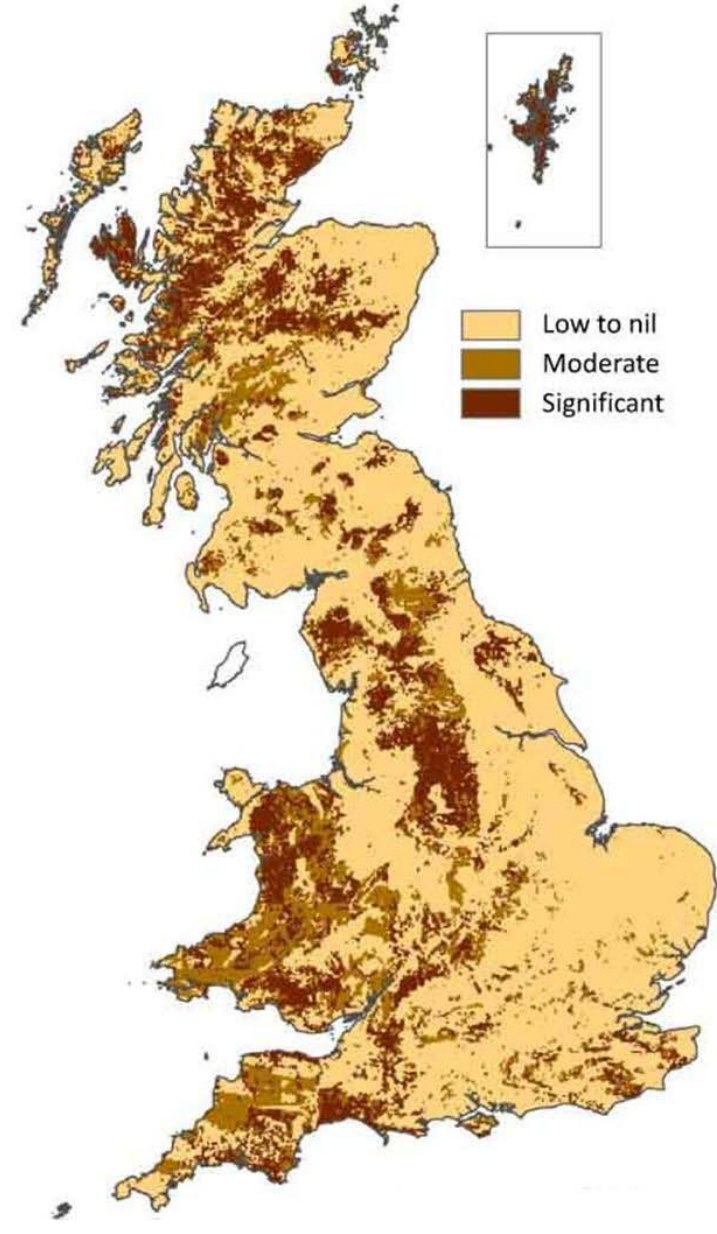

Figure 4 Simplified map of landslide potential (GeoSure). BGS (C) NERC 2015. All rights reserved. Contains Ordnance Survey data (coastline) C Crown copyright and database right 2015.

(British Geological Survey, 2013). The collaboration between the public sector organisations aims to provide targeted information to agencies, assisting their roles in hazard preparation. A daily report brings together scientific expertise from across the partners enabling a coordinated and coherent advice source for the government and emergency community.

The BGS issues a daily landslide hazard warning directly to the NHP and its stakeholders. This hazard warning is primarily based on recent and historic landslide information in the NLD as well as new information received on a daily basis from media search engines and social media. These events are used in conjunction with forecasted and antecedent rainfall, BGS landslide susceptibility maps (GeoSure) and expert judgement to indicate the likelihood of landslides occurring for the upcoming 24-hour period on a regional basis. This is highlighted using a traffic-light ${ }^{\text {plus }}$ system (green, yellow, amber and red). Regionally specific comments and notifications are included as required, using NLD records of events, landslides hazard expertise and regional knowledge (Met Office, 2013; British Geological Survey, 2013). 


\subsection{Hazard Impact Model}

GeoSure and the NLD are essential components of the contribution made by BGS to the production of Daily Hazard Assessments issued through the NHP. Although in its infancy, the NHP cross-agency collaboration aspires to combine data and expertise to identify areas and assets most vulnerable to a particular hazard. It aims to establish a world-leading hazard impact forecasting service (Public Health England, 2013). The method requires cross-agency development of a model that can reflect a changing situation over time, which is also capable of being sensitive to the vulnerability of different types of infrastructure, hazards and the general population.

The future creation of a Hazard Impact Model (HIM) as part of this research will rely heavily on the data gathering activities of the NLD in order to populate a hazard impact library (Taylor et al., 2014) which can be related to types and magnitudes of landslides. The BGS NLD will provide temporal and spatial information regarding the occurrence and nature of contemporary landslide events. Further data on duration (e.g. the length of subsequent road/rail closures or travel disruption), spatial (areas affected) and social impacts (e.g. injuries, death, closed businesses and amenities) following these events will be gathered from linked references cited within the NLD. Gathering and recording such data will enable an assessment of the potential impacts of different sized events occurring in susceptible areas. The impact of these landslide events on the infrastructure network can then be modelled with regard to asset vulnerability and traffic density. Capturing this information in such a model will identify when and where to issue landslide hazard alert warnings, to prioritise and assist deployment of 'responder' services in at risk areas (Bee, 2012).

\subsection{Landslide Domains}

The need to develop a national map that characterises landslides across Great Britain has increasingly been recognised and the BGS is adopting a land systems mapping approach to create it. This work is currently under development and aims to contribute to the continued augmentation of the national landslide susceptibility map, the needs of asset and infrastructure managers and the work being undertaken to identify the impact of climate change on slopes. The development of a series of hierarchical landslide domains underpins the application of modelling techniques which can be applied to determine how different types of landslides and terrains will be affected by precipitation (Dashwood et al., in press).

Previous experience of developing national maps of both Quaternary and Till domains has provided a framework for creating a national landslide domain map which follows the principles of terrain/land systems mapping which originated in the 1930-40s in

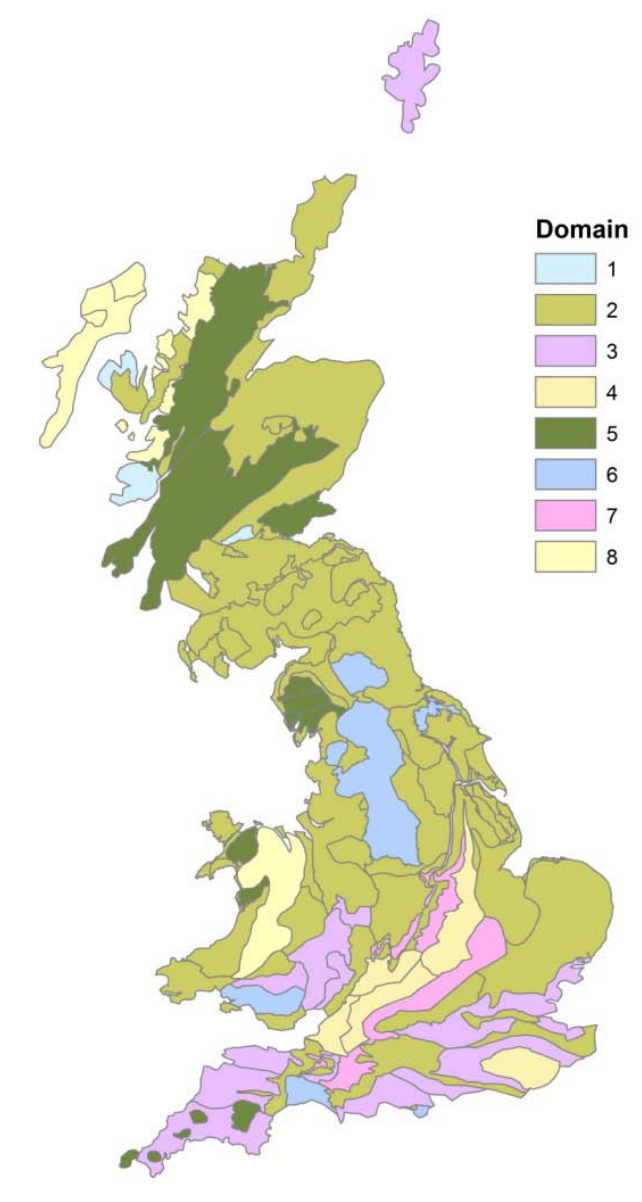

Figure 5 The Landslide Domains map of Great Britain (taken from Dashwood et al. in press). See Table 1 for explanation of each domain. BGS C NERC 2015. All rights reserved. Contains Ordnance Survey data (coastline) (c) Crown copyright and database right 2015. 
Australia (Christian, 1958). This uses a hierarchical approach which allows a large area to be broken down systematically into smaller units depending on geology, hydrology and geomorphology. Eyles (1983) used the approach for mapping glacial terrains and identified the genetic relationship between landforms and the processes and materials involved in their development; Griffiths et al. (2005) established that terrain systems mapping can provide an effective tool in the investigation of landslide distributions at a regional scale. According to the Australian Geomechanics Society (2000) identification of landslides requires an understanding of slope processes and the relationship of these to geomorphology, geology, hydrogeology, climate and vegetation. With these factors in mind the datasets that were interrogated include geological maps, digital topographic data, the NLD and the Quaternary domain map (Booth et al., 2012). The National landslide Database was used as a starting point to identify areas of distinct clusters of landsliding and to assess the factors which were likely to be related to this increased incidence of failures. Where possible these factors were used to delineate areas where a certain type of landsliding was likely to occur. For instance where landslides were focussed on a particular geology linked to a topographic feature such as an escarpment a domain could be interpreted using these factors.

Table 1 Landslide domain name and summary (after Dashwood et al. in press).

\begin{tabular}{|c|c|c|}
\hline $\begin{array}{l}\text { Domain } \\
\text { Number }\end{array}$ & Domain name & Summary \\
\hline 1 & $\begin{array}{l}\text { Large, deep seated } \\
\text { rotational landslides }\end{array}$ & Large, deep seated rotational landslides-lithologically and structurally controlled. \\
\hline 2 & $\begin{array}{l}\text { Modern river valley } \\
\text { landslides }\end{array}$ & $\begin{array}{l}\text { Landslides predominantly controlled by the presence of modern river valleys. } \\
\text { Gently undulating low-relief landscapes, spreads of weathered till, drumlins, } \\
\text { dissected by palaeo and modern river valleys with associated valley side } \\
\text { rotational and planar landslides. }\end{array}$ \\
\hline 3 & $\begin{array}{l}\text { Shallow rotational and } \\
\text { translational } \\
\text { landslides }\end{array}$ & $\begin{array}{l}\text { Shallow rotational and planar landslides controlled by processes in a weathered } \\
\text { zone, both in bedrock and in superficial veneer, involving contemporary } \\
\text { landsliding as well as more ancient landsliding. }\end{array}$ \\
\hline 4 & $\begin{array}{l}\text { Cambering and } \\
\text { rotational landslides }\end{array}$ & $\begin{array}{l}\text { Cambering and rotational landslides involving clay rich bedrock leading to e.g. } \\
\text { spreads in the Weald and cambering and rotational landslides in the Cotswolds. }\end{array}$ \\
\hline 5 & $\begin{array}{l}\text { Rock falls and slides } \\
\text { with debris flows }\end{array}$ & $\begin{array}{l}\text { Bedrock controlled rock slope failures, including falls, toppling/spreading, rock } \\
\text { creep, translational landslides occurring in harder bedrock with V-shaped valleys } \\
\text { and including some large rock slope failures in western Scotland. Large rock slope } \\
\text { failures in an eroded, rounded bedrock geomorphology with U-shaped valleys. } \\
\text { Flows and landslides in superficial deposits are also present. }\end{array}$ \\
\hline 6 & $\begin{array}{l}\text { Deep seated rotational } \\
\text { landslides with flows }\end{array}$ & $\begin{array}{l}\text { Deep seated rotational landslides, often degrading into flows, in plateau and } \\
\text { valley landscapes mainly where competent bedrock is overlying incompetent } \\
\text { bedrock. Landslides also occur in till and head deposits, mainly along river valleys } \\
\text { sides. }\end{array}$ \\
\hline 7 & $\begin{array}{l}\text { Shallow rotational } \\
\text { landslides and flows }\end{array}$ & $\begin{array}{l}\text { Escarpment cap-rock related landslides, mostly involving shallow rotational } \\
\text { landslides; occurring in harder or more resistant rock type overlying a weaker or } \\
\text { less resistant rock type. The majority of landslides are shallow rotational features } \\
\text { with a strong flow element. }\end{array}$ \\
\hline 8 & $\begin{array}{l}\text { Shallow landslides in } \\
\text { weathered bedrock } \\
\text { (regolith) }\end{array}$ & $\begin{array}{l}\text { Bedrock controlled landslides in thin regolith in landscapes that are glacially } \\
\text { eroded and smoothed with ice scoured hard bedrock, or involve hard bedrock. } \\
\text { Landslide occurrence controlled by the presence of weathered bedrock material } \\
\text { and thin superficial deposits. }\end{array}$ \\
\hline
\end{tabular}

The Landslide Domain Map (Fig. 5) has been subdivided into domains which provide information on large scale patterns of landsliding and influence of strata, akin to the landslide-prone strata and subdomains as defined by Jones and Lee (1994), to provide more detail and resolution. The map 
identifies eight large-scale domains, each of which has different dominant landslide types and associated minor landslide types where applicable (Table 1). The majority of the domains are strongly influenced by bedrock geology and the associated control this exerts over topography. The domains are divided into subdomains to enable further differentiation to be made regarding the geological and geomorphological drivers within that area.

The completed domain map and its accompanying descriptions of sub domains will be accessible via the BGS website and will provide summary information on the types, scale, magnitude and frequency of landslides that have been recorded and will be expected to occur in a region. Further research within BGS on the best models to use for landslide susceptibility will utilise the domains to assess which type of model can best represent the instability conditions. For instance in some subdomains the application of separate rock fall or debris flow models will be undertaken alongside the current national landslide susceptibility map, GeoSure.

\subsection{Rainfall Thresholds}

During a very wet period from April 2012 to January 2013, the central and southern parts of the UK received in many places more than $135 \%$ of the long term average rainfall and experienced a large number of landslides (Pennington and Harrison, 2013; Fig. 1). Some $43 \%$ of these landslides events involve small-scale slumps or flows affecting engineered earthwork slopes of transport infrastructure embankments and cuttings. Reports indicated that triggering of these events predominantly takes place during, or shortly after intense rainfall, suggesting that relatively short term, intense rainfall may form a suitable threshold to describe these occurrences. However, there is an apparent delay in the rise of the number of landslides from when this wet period commenced. The very wet conditions of April 2012 did not generate many landslides as soil moisture conditions were very dry due to lower than average rainfall in the preceding 18 months. A major increase in the number of events was not observed until July 2012, some four months after very wet conditions had started. Similarly, it can be observed that the landscape continued to suffer an enhanced sensitivity well into 2013; some three months after rainfall conditions had subsided to be in line with the long term average. A similar pattern can be observed in the period from October 2013 to March 2014. It is apparent therefore that conditioning of the landscape by rainfall deviating from the long term average over a number of months is an important additional threshold that needs considering - an observation that has been highlighted in a British context by, for example, Collison et al. (2000), Dixon and Brook (2007) and Dijkstra and Dixon (2010) and elsewhere (e.g. Glade et al., 2000;

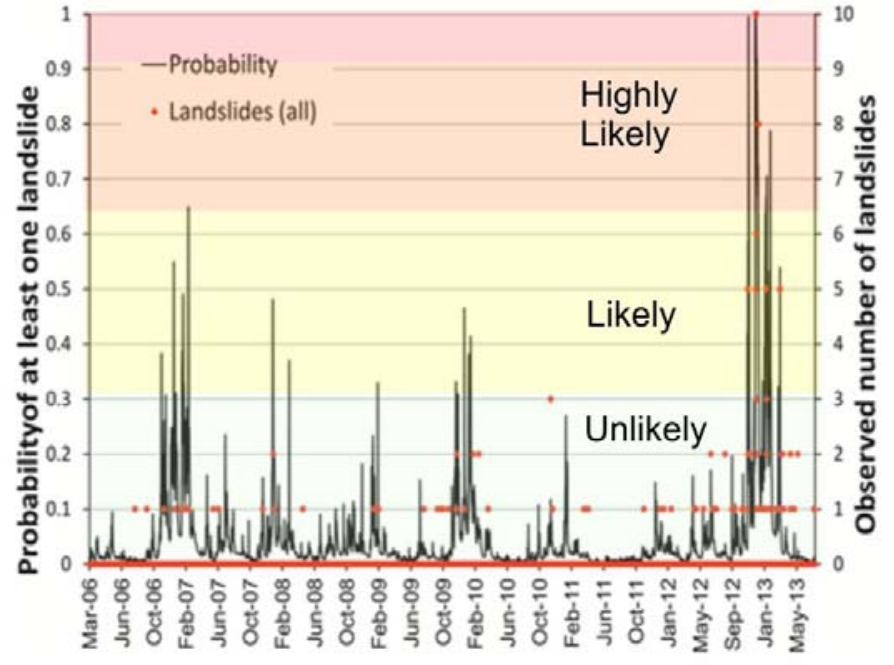

Figure 6. The probability of at least one occurrence of any type of landslide on a given date taking into account antecedent precipitation conditions (after Pennington et al., 2014). 
2012).

To analyse the potential establishment of rainfall triggers a regional assessment of antecedent effective rainfall and landslide occurrence was carried out for SW England and S Wales using data from the NLD and rainfall statistics from the Met Office and Wunderground.com (Pennington et al. 2014). Here, the authors highlighted two significant trends - a long-term gradual accumulation from 7 to 90 days before the events occurred and a higher intensity rainfall accumulation rate in the 7 days leading to failure. They established that, for the period from March 2006 until April 2013, antecedent effective rainfall over 1, 7 and 90 days provided the best information that can be used to compute the probability of at least one landslide being triggered by rainfall (Fig. 6). This analysis provides an opportunity to evaluate the changing probability of landslides occurring in response to antecedent effective rainfall, but it must be emphasised that this analysis needs further work as it, for example,(i) incorporated different modes of failure (although dominated by shallow translational events and flows, larger slides were also included), (ii) covered a large area represented by regional rainfall characteristics of poor local specificity, and (iii) used this as a proxy for shear strength fluctuations that are assumed to be driven by pore pressure changes that in turn are the consequence of sequences of rainfall events (see e.g. van Asch et al., 1999; van Westen et al., 2006). For example, being able to model soil moisture (and pore pressures) more directly would be a great advantage (e.g. Ponziani et al., 2012), but this requires further research to achieve a better parameterisation of the UK landscape. The antecedent effective rainfall threshold analysis is a reflection of historical patterns and is therefore based on the assumption that there is continuity in the modes of failure, precipitation-pore pressure pathways and thresholds that trigger these events. This is, however, not necessarily the case as slope response to rainfall events can be subject to its own intrinsic threshold transgressions. For example, if engineered slopes constructed in plastic clays dry out under end-of-summer conditions, fissure networks may be formed that may enable wetting up of critically weak surfaces at depth once autumn rainfall occurs (e.g. Dijkstra and Dixon, 2010; Clarke and Smethurst, 2010). Many such scenarios, with subtle differences in the plausible pathways describing the links between rainfall and shear strength loss, can be narrated. Thus, even though these simple antecedent effective rainfall thresholds can act as a pragmatic indicator for slope stability evaluation over relatively short forecasting timescales, for longer term assessment of landscape instability in response to changing meteorological conditions in a context of climate change it is necessary to follow approaches that see these landscapes as dynamic, rather than steady state systems. This necessitates the development of slope stability models that are better able to incorporate the probabilistic outputs of climate change forecasts such as UKCP09 (Jenkins et al., 2009) and capable of representing the effects of changing hydrological pathways that lead to slope failure (e.g. Dijkstra and Dixon, 2010).

\section{Communication}

As a national geological survey, communication of landslide research involves balancing peer-review scientific papers with, for example, the interest of a home owner or student. The Internet is an excellent portal for tiered communication, addressing both the scientific and non-scientific communities.

Public sector information providers, such as the BGS, are able to publish data under the Open Government Licence (The National Archives, 2014), which enables the free re-use of government and public sector data under a common authorisation. Selected information from the NLD is 
available as a free online resource via the BGS online GIS - the Geolndex (British Geological Survey, 2014a). Users can obtain landslide point index data including name, location and reference information. The point symbols at the designated location do not reflect the size and shape of the corresponding landslide, only the recorded presence of a landslide within a range of accuracy.

An educational resource (British Geological Survey, 2014b) has been designed to assist all capacities and levels of research and includes nomenclature, direct links to published papers, reports, updates on current research and a suite of landslide field survey reports. This increases visibility and knowledge access and encourages dialogue between a government scientific organisation and the general public. This is in addition to the use of social media platforms and proffers direct links with experts and valued data collection opportunities.

Information from the NLD and other national geological datasets is also available through a bespoke report. The Landslides GeoReport provides cost-effective access to unique sources of published and unpublished geological data. The data are combined with scientific expertise to produce a commissioned report about the landslide conditions in a given area.

\section{Conclusion}

The BGS are continuously collecting new and historic data at national, regional and site-specific scales for landslides and slope failures in Great Britain with the aim to improve the knowledge of their spatial and temporal distribution as well as to further understand landslide processes. This work underpins the development of research into future scenario and forecast modelling for a national daily hazard assessment, landslide domain mapping and to further the research into rainfall thresholds. The data are collected from a range of sources including social media since August 2012. This has seen over a fifteen-fold increase in the number of landslides captured in the NLD per year. The data are communicated in a variety of ways and the database is freely available via an online GIS.

\section{Acknowledgements}

This paper is published with the permission of the Executive Director of the British Geological Survey (NERC). The authors would like to thank Vanessa Banks, Hannah Jordan, Peter Hobbs, Emma Ward, Anna Harrison, Gareth Jenkins, David Boon, Ashley Patton and Helen Reeves.

\section{References}

Australian Geomechanics Society, 2000. Landslide Risk Management Concepts and Guidelines. Australian Geomechanics. Australian Geomechanics Society Landslide Risk Management subcommittee, 51-92.

Bee, E., 2012. The Natural Hazards Partnership: Sharing the power of place to develop and deliver more targeted information about natural hazards for UK Government and the emergency response and resilience community. Accessed July 2014. http://www.agi.org.uk/storage/GeoCommunity/AGI12/Presentations/EmmaBee.pdf. 
Booth, K. A., Booth, S. J., Slater, C., 2012. BGS Geological Cross Sections and Quaternary Domains: User Guidance Notes, OR/10/30. British Geological Survey, Nottingham, UK, 36 pp.

Bossu, R., 2013. Towards citzen seismology, Face au risqué, December 2013. Accessed July 2014. http://www.citizenseismology.eu/docs/Citizen-Seismology.pdf

British Geological Survey, 2007. Report A Landslide. British Geological Survey web page, accessed July 2014. http://www.bgs.ac.uk/landslides/report.html

British Geological Survey, 2012a. Rothbury landslide: the impact of a landslide on the local economy, British Geological Survey web page, accessed July 2014.

http://www.bgs.ac.uk/landslides/rothbury.html

British Geological Survey, 2012b. Burton Bradstock rock fall, Dorset, British Geological Survey web page, accessed July 2014, accessed July 2014.

http://www.bgs.ac.uk/landslides/burtonbradstock.html

British Geological Survey, 2013. Natural Hazards Partnership. British Geological Survey web page, accessed July 2014. http://www.bgs.ac.uk/research/earthHazards/naturalHazardsPartnership.html

British Geological Survey, 2014a. The Geolndex. British Geological Survey web page, accessed July 2014.http://www.bgs.ac.uk/geoindex

British Geological Survey, 2014b. Landslides. British Geological Survey web page, accessed July 2014.http://www.bgs.ac.uk/landslides

Christian, C E., 1958. The concept of land units and land systems. Proceedings of the Ninth Pacific Science Congress. Special Symposium on Climate, Vegetation, and Rational Land Utilization in the Humid Tropics. UNESCO, Bangkok, Thailand, 169 pp.

Clarke, D., Smethurst, J. A., 2010. Effects of climate change on cycles of wetting and drying in engineered clay slopes in England. Quarterly Journal of Engineering Geology and Hydrogeology 43, 473-486.

Collison, A., Wade, S., Griffiths, J., Dehn, M., 2000. Modelling the impact of predicted climate change on landslide frequency and magnitude in SE England. Engineering Geology 55, 205-218.

Cooper, R. G., 2007. Mass Movements in Great Britain, Geological Conservation Review Series, No. 33. Joint Nature Conservation Committee, Peterborough, UK, 348 pp.

Dashwood, C., Banks, V.J., Dijkstra, T. A., Freeborough, K. A., Harrison, A. M., Hobbs, P.R.N., Pennington, C. V. L., Reeves, H. J. (in press), A national scale geomorphological domains approach for assessing the occurrence and types of landsliding of Great Britain.

Dashwood, C., Diaz Doce, D., Lee, K. A., 2014. GeoSure Version 7 Methodology: Landslides Slope Instability. Internal Report IR/14/014. British Geological Survey, Nottingham, UK, 31 pp. 
Dijkstra, T. A., Dixon, N., 2010. Climate change and slope stability in the UK: challenges and approaches. Quarterly Journal of Engineering Geology and Hydrogeology 43, 371-385.

Dixon, N., Brook, E., 2007. Impact on landslide reactivation: case study on Mam Tor, UK. Landslides 4, 137-148.

Doan, S., Vo, B-K. H., Collier, N., 2012. An analysis of Twitter Messages in the 2011 Tohoku Earthquake. Social Informatics and Telecommunications. Engineering 91, 58-66.

Earle, P. S., Bowden, D. C., Guy, M., 2011. Twitter earthquake detection: earthquake monitoring in a social world. Annals of Geophysics 546, 708-715.

Early, K.R., Skempton, A., 1972. Investigation of the landslide at Walton's Wood, Staffordshire. Quarterly Journal of Engineering Geology and Hydrogeology 5, 19-41.

Evans, H. M., Pennington, C. V. L., Jordan, C., Foster, C., 2013. Mapping a nation's landslides: a novel multi-stage methodology. In: Margottini, C., Canuti, P., Sassa, K. (Eds.), Landslide Science and Practice: Landslide Science and Practice 1. Springer-Verlag, Berlin, Germany, pp. 21-27.

Eyles, N., 1983. Glacial Geology: An Introduction for Engineers and Earth Scientists. Pergamon Press, Oxford, UK, 409 pp.

Foster, C., Pennington, C. V. L., Culshaw, M. G., Lawrie, K., 2012. The National Landslide Database of Great Britain: development, evolution and applications. Environmental Earth Sciences 663, 941-953.

Gibson, A. D., Humpage, A. J., Culshaw, M. G., Forster, A., Waters, R. A., 2002. The geology and landslides of Nefyn Bay, Gwynedd. In: Nichol, D., Bassett, M. G., Deisler, V. K. (Eds.), Landslides and landslides management in North Wales. Geological Series No 22. National Museums and Galleries of Wales. Cardiff, UK, pp. 14-17.

Gibson, A. G., Culshaw, M. G., Dashwood, C., Pennington, C. V. L., 2013. Landslide management in the UK-the problem of managing hazards in a 'low-risk' environment. Landslides 20, 599-610.

Glade, T., Crozier, M., Smith, P., 2000. Applying probability determination to refine landslidetriggering rainfall thresholds using an empirical "Antecedent Daily Rainfall Model". Pure and Applied Geophysics 157, 1059-1079.

Griffiths, J. S., Hart, A. B., Mather, A. E., Stokes, M., 2005. Assessment of some spatial and temporal issues in landslide initiation within the Rio Aguas Catchment, South-East Spain. Landslides 23, 183192.

Guzzetti, F., Peruccacci, S., Rossi, M., Stark, C. P., 2007. Rainfall thresholds for the initiation of landslides in central and southern Europe. Meteorology and Atmospheric Physics 98, 239-267.

Jenkins, G.O., Hobbs, P.R.N., 2007. Report of walkover survey and desk study of the South Beach landslide, Whitehaven Cumbria, British Geological Survey Report IR/07/002, 16 pp. 
Jenkins, G. J., Murphy, J. M., Sexton, D. M. H., Lowe, J. A., Jones, P., Kilsby, C. G., 2009. UK Climate Projections: Briefing report. Met Office Hadley Centre, Exeter, UK, 10 pp.

Jones, D. K. C., Lee, E. M., 1994. Landsliding in Great Britain, Department of the Environment, HMSO, Norwich, UK, $361 \mathrm{pp}$.

Lee, E.M., 1999. Coastal planning and management: the impact of the 1993 Holbeck Hall landslide, Scarborough: East Midlands Geographer 21, 78-91.

Martelloni, G., Segoni, S., Fanti, R., Catani, F., 2012. Rainfall thresholds for the forecasting of landslide occurrence at regional scale. Landslides 9, 485-495.

Met Office, 2013. Natural Hazards Partnership. Met Office web page, accessed July 2014. http://www.metoffice.gov.uk/nhp/

Nyquist, C., 2012. Did you see a landslide? Unites States Geological Survey web page, accessed July 2014.http://www.usgs.gov/blogs/features/usgs top story/did-you-see-a-landslide/

Pennington, C. V. L., Harrison, A. M., 2013. 2012 - a landslide year? GeoScientist magazine, Geological Society of London 23, 10-15.

Pennington, C. V. L., Foster, C., Chambers, J., Jenkins, G. O., 2009. Landslide research at the British Geological Survey: capture, storage and interpretation on a national and site-specific scale. Acta Geologica Sinica 836, 801-840.

Pennington, C. V. L., Dijkstra, T. A., Lark, M., Dashwood, C., Harrison, A. M., Freeborough, K. A., 2014. Antecedent precipitation as a potential proxy for landslide incidence in SW UK. In: Sassa, K., Canuti, P. Yin, Y. (Eds.), Landslide Science for a Safer Geoenvironment 1. Springer International Publishing, Switzerland, pp. 253-269.

Ponziani, F., Pandolfo, C., Stelluti, M., Berni, N., Brocca, L., Moramarco, T., 2012. Assessment of rainfall thresholds and soil moisture modeling for operational hydrogeological risk prevention in the Umbria region (central Italy). Landslides 9, 229-237.

Public Health England, 2013. Natural Hazard Partnership webpage, accessed July 2014. http://www.hpa.org.uk/Topics/EmergencyResponse/ExtremeWeatherEventsAndNaturalDisasters/N aturalHazardsPartnership/

Savran, W. H., Petersen, R. I., Wukusick, M., 2013. Smartphone interface to USGS 'Did you feel it?' getting more citizens involved in science. American Geophysical Union, Fall Meeting 2013, Poster. http://sci.sdsu.edu/geology/smartphone-interface-to-usgs-did-you-feel-it-getting-more-citizensinvolved-in-science/

Shanley, L., 2013. Citizen Science - what's policy for to do with it? American Geophysical Union, Fall Meeting 2013, Poster. http://adsabs.harvard.edu/abs/2013AGUFMGC11B0991S 
Skempton, A., Weeks, A., 1976. The Quaternary history of the Lower Greensand escarpment and Weald Clay vale near Sevenoaks, Kent. Philosophical Transactions of the Royal Society of London 283, 493-526.

Stollberg, B., de Groeve, T., 2012. The Use of Social Media within the Global Disaster Alert and Coordination System GDACS. Proceedings of the 21st International Conference Companion on World Wide Web, pp. 703-706.

Taylor, F. E., Freeborough, K. A., Malamud, B. D. and Demeritt, D., 2014. A method to add Richness to the National Landslide Database of Great Britain, European Geosciences Union 2014 General Assembly, Session NH3.14, Poster B2488.

Taylor, F. E., Freeborough, K. A., Malamud, B. D. and Demeritt, D., this issue. Increasing the richness of the National Landslide Database of Great Britain by searching local newspaper archives, Geomorphology.

The National Archives, 2014. Open Government Licence for public sector information. The National Archives web page, accessed July 2014. http://www.nationalarchives.gov.uk/doc/open-governmentlicence/version/2/

van Asch, T. W. van, Buma, J., Van Beek, L. P. H., 1999. A view on some hydrological triggering systems in landslides. Geomorphology 30, 25-32.

van Westen, C. J., Van Asch, T. W., Soeters, R., 2006. Landslide hazard and risk zonation-why is it still so difficult? Bulletin of Engineering geology and the Environment 65, 167-184.

Winter, M. G., Dent, J., Macgregor, F., Dempsey, P. Motion, A., Shackman, L., 2010. Debris flow, rainfall and climate change in Scotland. Quarterly Journal of Engineering Geology and Hydrogeology $43,429-446$. 